\title{
Yield and Nutritional Response of Greenhouse Grown Tomato Cultivars to Sustainable Fertilization and Irrigation Management
}

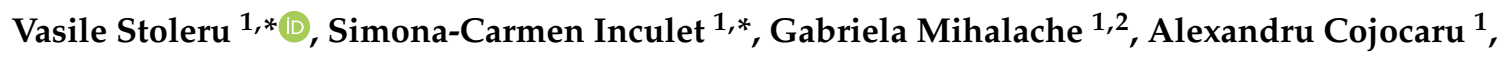 \\ Gabriel-Ciprian Teliban ${ }^{1}$ and Gianluca Caruso ${ }^{3}$ \\ 1 Department of Horticultural Technologies, "Ion Ionescu de la Brad" University of Agricultural Sciences and \\ Veterinary Medicine, 3 M. Sadoveanu, 700440 Iasi, Romania; gabriela.mihalache.gm@gmail.com (G.M.); \\ cojocaru.alexandru@yahoo.com (A.C.); gabrielteliban@uaiasi.ro (G.-C.T.) \\ 2 Integrated Center of Environmental Science Studies in the North East Region (CERNESIM), \\ The "Alexandru Ioan Cuza" University of Iasi, 700449 Iasi, Romania \\ 3 Department of Agricultural Sciences, University of Naples Federico II, Naples, 80055 Portici, Italy; \\ gcaruso@unina.it \\ * Correspondence: vstoleru@uaiasi.ro (V.S.); simona_inculet@yahoo.com (S.-C.I.)
}

Received: 3 July 2020; Accepted: 17 August 2020; Published: 18 August 2020

\begin{abstract}
Tomato is considered one of the most important crops worldwide from nutritional and economic standpoints, and, in this respect, sustainable production should be a prime objective, particularly in terms of fertilization and irrigation management. The aim of this study was to compare the effects of two fertilization types (chemical or organic) and two irrigation regimes (67\% or 100\% of evapotranspiration replenishment) on biometrical, biochemical, and yield parameters of three indeterminate cultivars of tomato grown in a greenhouse. The results showed that the effect of organic fertilization was better compared to chemical fertilization for lycopene accumulation and antioxidant activity, as well as for the lower concentrations of any of the macroelements in the tomato fruits; therefore, organic fertilization can be used as an alternative to chemical fertilization in sustainable horticulture. In each cultivar under the same fertilization type, the effect of irrigation was significant on yield and the number of fruits, but the 100\% evapotranspiration restoration did not enhance the fruit concentration of all the macroelements and microelements compared to $67 \%$ irrigation regime. Higher concentrations of macro- and microelements in the chemically fertilized fruits compared to the organic ones, regardless of the cultivar and the irrigation regime, suggest that the inorganic substances are more easily absorbed by plants under a protected environment. Organic fertilization positively affected the lycopene and antioxidant activities of tomato fruits, thus proving to be a valuable alternative to chemical fertilization in sustainable agriculture, although the product premium quality also depends on the cultivar used.
\end{abstract}

Keywords: Solanum lycopersicum L.; organic fertilization; irrigation regime; production; antioxidants; mineral elements

\section{Introduction}

Tomato (Solanum lycopersicum L.) is one of the main cultivated vegetables in the world [1], and, in Romania, it is grown as forced and protected crops on about 50,000 ha, which is equivalent to $60-65 \%$ of the cultivable area in greenhouses [2]. The economic importance of this crop is due to the staggered use of labor as a result of the different systems and forms of cultivation, the high yields, and the resulting income [3]. The regular consumption of fresh and processed tomatoes has been associated with a low incidence of various types of cancer, considering the high content of antioxidant compounds [4]. Indeed, 
the added nutritional value of tomato fruits is represented by secondary metabolites with antioxidant properties, such as lycopene, $\alpha$ - and $\beta$-carotene, violaxanthin, neoxanthin, lutein, zeaxanthin, $\alpha$ - and $\beta$-cryptoxanthin, neurosporene, phytoene, phytofluene, cyclolopene, $\mathrm{p}$-coumaric acid, and rutoside. $\alpha$-and $\beta$-carotene, as well as $\beta$-cryptoxanthin, are important sources of vitamin $A$, known to increase both the humoral and cellular responses [5], whereas lycopene is a carotenoid that reduces the risk of chronic diseases such as cancer and cardiovascular disease [4]. The antioxidant activity of tomato fruits depends on the genotype, but also on the maturation stage, cultivation practices (water availability, mineral nutrients), and climate (mostly light and temperature) [6]. Various studies have shown values of lycopene content in tomato fruits ranging from 1.66 to $39.7 \mathrm{mg} \cdot \mathrm{g}^{-1} \mathrm{~d}$.w. (dry weight), depending on the cultivars used, but in the latest high-lycopene (HLY) lines, the level of lycopene can be significantly higher [7]. The antioxidant accumulation in the fruits is also affected by the crop system. Nutrition management plays a major role [5,6], and indeed, specialized production is oriented to meet the increased consumer demands for organic products, characterized by reduced use of chemical inputs [8].

Previous research on tomato [9] showed no significant differences between organic and conventional management on yield components, as well as on plant biomass and leaf area. The organic fruits had a higher concentration of sulfur, organic acids, and vitamin C, as well as higher lipophilic antioxidant activity. However, no significant differences were recorded for the polyphenols and the hydrophilic antioxidant activity, whereas a higher lycopene concentration was detected in the conventional fruits. In other vegetable crops such as asparagus (Asparagus officinalis) [10], conventional management led to higher yields, whereas organic management increased the mean weight per shoot, as well as the sugar concentration of the shoots. Similarly, red basil (Ocimum basilicum "Purpurascens") showed higher yield under chemical management and enhanced anthocyanins concentration and antioxidant activity in the organically grown leaves [11]. Chemical fertilization is still one of the major agricultural practices to achieve high yields, but organic fertilization represents a viable alternative to obtain high tomato fruit quality, mineral composition, and taste, which are also affected by cultivar [12,13]. Investigations have been carried out on the effects of the aforementioned factors on the nutritional and organoleptic characteristics of tomato fruit $[9,14]$, as well as related species such as eggplant [15-17] and early potato [18]. Open field research has demonstrated the significant effects of unconventional fertilization (biologic or organic) on the nutrient composition of tomato fruits [8,12]. Many studies have highlighted the remarkable concentration of minerals such as $\mathrm{K}, \mathrm{P}$, and $\mathrm{Mg}$ in tomato fruits [9,13,19], which are essential for the human organism. In this respect, the consumption of one portion of $200 \mathrm{~g}$ tomatoes represents $11 \%, 7.5 \%$, and $5 \%$ of the recommended daily dose for adults of $\mathrm{K}, \mathrm{P}$, and $\mathrm{Mg}$, respectively.

The aim of this study was to compare the effects of chemical and organic fertilization, in factorial combination with $67 \%$ and $100 \%$ evapotranspiration (ET) replenishment, on yield, growth, antioxidants, and elemental composition of tomato fruits of three cultivars grown in a greenhouse in the northeastern area of Romania.

\section{Results and Discussion}

\subsection{Biometrical and Yield Parameters}

As there were no interactions between the year of research and the three experimental factors applied for any measured parameters, all the values are reported as means of the two investigation years (Table 1).

Fertilization type or irrigation regime significantly influenced the tomato plant height, contrasting with the reports of other authors [20]. However, in terms of yield, cultivar HTP $\mathrm{F}_{1}$ showed a $29.5 \%$ higher value than IB, owing to a higher (10.5\%) number of fruits per plant and a higher mean weight per fruit.

The fertilization type did not significantly influence either the tomato plant height or yield components. The lack of significant fertilization effects may be attributed to the fact that the organic fertilizers release the nutrients slowly, compared to chemical ones, and, indeed, organic fertilization resulted in a lower number of fruits that reached a higher individual weight, although the difference 
was not significant [21]. In previous research [22], processing tomato cultivated in an organic cropping system showed reductions of leaf area $(-36 \%)$, which led to lower fruit yield and total biomass dry weight $(-25 \%)$.

Table 1. Influence of the experimental treatments on plant height and yield components.

\begin{tabular}{|c|c|c|c|c|}
\hline Treatment & $\begin{array}{l}\text { Plant Height at } \\
\text { Last Harvest }(\mathrm{cm})\end{array}$ & $\begin{array}{c}\text { Number of Fruits } \\
\text { per Plant }\end{array}$ & $\begin{array}{l}\text { Mean Weight Per } \\
\text { Fruit (g) }\end{array}$ & Yield (t.ha $\left.{ }^{-1}\right)$ \\
\hline \multicolumn{5}{|l|}{ Year } \\
\hline 2018 & 217.0 & 23.7 & 167.6 & 135.6 \\
\hline \multirow[t]{2}{*}{2019} & 213.8 & 23.3 & 167.0 & 134.0 \\
\hline & ns & ns & ns & ns \\
\hline \multicolumn{5}{|l|}{ Cultivar } \\
\hline Siriana $F_{1}(S)$ & $206.4 \pm 14.6$ & $24.1 \pm 1.64 \mathrm{a}$ & $161 \pm 11$ & $134.4 \pm 7.0 \mathrm{ab}$ \\
\hline $\mathrm{HTP}_{1}(\mathrm{H})$ & $215.6 \pm 15.4$ & $24.3 \pm 1.65 \mathrm{a}$ & $183 \pm 13$ & $152.4 \pm 8.4 \mathrm{a}$ \\
\hline Inima de Bou (IB) & $\begin{array}{c}224.2 \pm 15.9 \\
\mathrm{~ns}\end{array}$ & $22.0 \pm 1.50 \mathrm{~b}$ & $\begin{array}{c}158 \pm 11 \\
\mathrm{~ns}\end{array}$ & $117.7 \pm 9.1 \mathrm{~b}$ \\
\hline \multicolumn{5}{|l|}{ Fertilization } \\
\hline Chemical (Ch) & $227.0 \pm 16.1$ & $24.2 \pm 1.7$ & $160 \pm 11$ & $130.9 \pm 10.2$ \\
\hline Organic (Og) & $\begin{array}{c}204.4 \pm 14.5 \\
\text { ns }\end{array}$ & $\begin{array}{c}22.7 \pm 1.6 \\
n s\end{array}$ & $\begin{array}{c}175 \pm 12 \\
\mathrm{~ns}\end{array}$ & $\begin{array}{c}134.3 \pm 10.4 \\
\text { ns }\end{array}$ \\
\hline \multicolumn{5}{|l|}{ Irrigation regime } \\
\hline $200 \mathrm{~m}^{3} \cdot \mathrm{ha}^{-1}$ & $215.6 \pm 15.3$ & $22.4 \pm 1.5 \mathrm{~b}$ & $160 \pm 11$ & $121.0 \pm 9.4 b$ \\
\hline $300 \mathrm{~m}^{3} \cdot \mathrm{ha}^{-1}$ & $\begin{array}{c}215.8 \pm 15.3 \\
\mathrm{~ns}\end{array}$ & $24.5 \pm 1.7 \mathrm{a}$ & $\begin{array}{c}175 \pm 12 \\
\mathrm{~ns}\end{array}$ & $144.3 \pm 11.2 \mathrm{a}$ \\
\hline
\end{tabular}

$200 \mathrm{~m}^{3} \cdot \mathrm{ha}^{-1}$ (67\% evapotranspiration (ET) replenishment); $300 \mathrm{~m}^{3} \cdot \mathrm{ha}^{-1}$ (100\% ET replenishment); ns: not statistically significant. Within each column and each experimental factor, different letters mean significant differences between the treatments, according to Tukey's test at $p \leq 0.05$.

Regarding the influence of the two irrigation regimes, statistically significant differences were recorded only for the fruit number per plant and the yield, which generally caused a decline in fruit weight. Indeed, the irrigation with $300 \mathrm{~m}^{3} \cdot \mathrm{ha}^{-1}$ resulted in a $19.3 \%$ higher yield compared to the $200 \mathrm{~m}^{3} \cdot \mathrm{ha}^{-1}$ irrigation regime. The results highlight the fact that when plants are grown in protected areas, the $100 \%$ replenishment of evapotranspiration is more favorable to yield as compared to $67 \%$ replenishment, presumably due to the fulfillment of the plants' water requirement [23]. Other authors [24] have reported that the reduction of $40 \%$ and $50 \%$ in leaf water potential generally caused a fruit weight drop, depending on cultivar and cluster. The water deficit treatment also affected the organoleptic characteristics of cherry tomato fruits and generally resulted in increased carotenoid concentration and decreased polyphenols, depending on the cultivar.

The results of the interactions between the three experimental factors applied (cultivar, fertilization type, irrigation regime) on the plant height, number of fruits per plant, mean fruit weight and yield are presented in Table 2.

No significant interactions between the experimental factors applied arose for tomato plant height (Table 2).

The fruit number per plant for Siriana $F_{1}$ cultivar, chemically fertilized and watered with $300 \mathrm{~m}^{3} \cdot \mathrm{ha}^{-1}$, showed a significant increase of $46.4 \%$ as compared to the organically fertilized plants irrigated with $200 \mathrm{~m}^{3} \cdot \mathrm{ha}^{-1}$. Significant differences were also recorded between S Ch 300 and IB Ch 200 , with a significantly lower number of fruits for cultivar IB, which was chemically fertilized and irrigated according to $67 \%$ ET.

Additionally, a tendency was observed for most of the plants treated with organic fertilizer, regardless of the water replenishment percentage, to have a lower fruit number per plant, though with no statistical significance, suggesting that chemical fertilization elicits a higher number of fruits.

The mean weight per fruit significantly increased by $41.2 \%$ from the experiment treatments $\mathrm{S} C \mathrm{C}$ and IB Og, both irrigated with $200 \mathrm{~m}^{3} \cdot \mathrm{ha}^{-1}$, to HTP Og 300. However, for all plants treated with the 
organic fertilizer, the mean weight per fruit was higher, even if not significantly, compared to the plants that received chemical fertilization (Table 1).

The highest yields were obtained for cultivar $\mathrm{HTP}_{1}$, organically fertilized and irrigated according to the $100 \%$ evapotranspiration replenishment, followed by Siriana $\mathrm{F}_{1} \mathrm{cv}$., chemically fertilized under the same irrigation regime. The lowest yield was recorded for the cultivar IB, chemically fertilized under the $67 \%$ water replenishment, which showed a $56.9 \%$ decrease compared to the top value. The lowest yield was recorded for the cultivar IB because it is not so well adapted for greenhouses, where the temperatures are higher and the air humidity is lower.

The aforementioned results are consistent with those reported under similar tomato crop management [25-27].

Table 2. Interaction between cultivar, fertilization type, and irrigation regime on plant height and yield components.

\begin{tabular}{ccccc}
\hline Treatment & $\begin{array}{c}\text { Plant Height at } \\
\text { Last Harvest }(\mathbf{c m})\end{array}$ & $\begin{array}{c}\text { Number of Fruits } \\
\text { Per Plant }\end{array}$ & $\begin{array}{c}\text { Mean Weight Per } \\
\text { Fruit (g) }\end{array}$ & Yield (t.ha $^{-\mathbf{1})}$ \\
\hline S Ch 200 & $216.83 \pm 15.38$ & $23.56 \pm 1.60 \mathrm{ab}$ & $148 \pm 1.00 \mathrm{~b}$ & $117.51 \pm 9.13 \mathrm{ab}$ \\
S Ch300 & $220.90 \pm 15.67$ & $28.41 \pm 1.93 \mathrm{a}$ & $160 \pm 1.10 \mathrm{ab}$ & $153.19 \pm 11.90 \mathrm{ab}$ \\
S Og200 & $199.52 \pm 14.16$ & $19.41 \pm 1.32 \mathrm{~b}$ & $163 \pm 1.10 \mathrm{ab}$ & $106.61 \pm 8.28 \mathrm{ab}$ \\
S Og300 & $188.32 \pm 13.36$ & $25.04 \pm 1.70 \mathrm{ab}$ & $174 \pm 1.21 \mathrm{ab}$ & $146.89 \pm 11.41 \mathrm{ab}$ \\
HTP Ch200 & $236.17 \pm 16.76$ & $24.97 \pm 1.70 \mathrm{ab}$ & $168 \pm 1.15 \mathrm{ab}$ & $141.37 \pm 10.98 \mathrm{ab}$ \\
HTP Ch300 & $221.92 \pm 15.74$ & $25.19 \pm 1.71 \mathrm{ab}$ & $171 \pm 1.15 \mathrm{ab}$ & $145.16 \pm 11.27 \mathrm{ab}$ \\
HTP Og200 & $204.61 \pm 14.52$ & $24.63 \pm 1.68 \mathrm{ab}$ & $184 \pm 1.25 \mathrm{ab}$ & $152.72 \pm 11.86 \mathrm{ab}$ \\
HTP Og300 & $203.59 \pm 14.44$ & $22.26 \pm 1.52 \mathrm{ab}$ & $209 \pm 1.43 \mathrm{a}$ & $157.12 \pm 12.20 \mathrm{a}$ \\
IB Ch200 & $235.15 \pm 16.68$ & $20.14 \pm 1.37 \mathrm{~b}$ & $147 \pm 1.01 \mathrm{~b}$ & $100.11 \pm 7.77 \mathrm{~b}$ \\
IBCh300 & $231.08 \pm 16.39$ & $22.78 \pm 1.55 \mathrm{ab}$ & $167 \pm 1.15 \mathrm{ab}$ & $128.20 \pm 9.96 \mathrm{ab}$ \\
IB Og 200 & $201.56 \pm 14.30$ & $21.56 \pm 1.47 \mathrm{ab}$ & $148 \pm 1.00 \mathrm{~b}$ & $107.53 \pm 8.35 \mathrm{ab}$ \\
IB Og 300 & $229.04 \pm 16.25$ & $23.44 \pm 1.60 \mathrm{ab}$ & $171 \pm 1.15 \mathrm{ab}$ & $135.08 \pm 10.49 \mathrm{ab}$ \\
& $\mathrm{ns}$ & & & \\
\hline
\end{tabular}

$\mathrm{S}$-Siriana $\mathrm{F}_{1} ; \mathrm{H}$ - $\mathrm{HTP} \mathrm{F}_{1}$; IB-Inima de Bou; Ch—chemical; Og—organic; 200 -200 $\mathrm{m}^{3} \cdot \mathrm{ha}^{-1}$ (67\% ET replenishment); 300-300 $\mathrm{m}^{3} \cdot \mathrm{ha}^{-1}$ (100\% ET replenishment); ns: not statistically significant. Within each column, different letters mean significant differences between the treatments, according to Tukey's test at $p \leq 0.05$.

\subsection{Fruit Antioxidant Compounds and Activity}

Lycopene is a carotenoid pigment found in red fruits and vegetables, and it is considered a powerful antioxidant [28]. In the present research, its concentration was $50 \%$ greater for the cultivars HTP and IB, organically fertilized under $100 \%$ evapotranspiration replenishment, compared to the cultivars Siriana $F_{1}$ and HTP, chemically fertilized and watered with $200 \mathrm{~m}^{3} \cdot \mathrm{ha}^{-1}$ (Figure 1).

Regardless of the cultivar, the lowest lycopene values were recorded in the tomato fruits of the plants chemically fertilized and irrigated with $200 \mathrm{~m}^{3} \cdot \mathrm{ha}^{-1}$. The higher lycopene concentration detected in the tomato fruits of the plants treated with organic fertilizer may be due to an intense chemical and biological activity in soils that are organically fertilized compared with soils that are chemically fertilized [21]. However, in other investigations carried out in the Mediterranean area, the lycopene concentration was higher in conventionally grown cherry tomato fruits [9] and under water deficit, depending on the cultivar [24], suggesting that the environment, farming management, and genotype may affect this antioxidant compound. It was also observed that at $472 \mathrm{~nm}$ wavelength, the lycopene values for most of the interactions were greater, though with no statistical significance as compared to those obtained at $502 \mathrm{~nm}$. Similar values of the lycopene content were obtained by Inculet et al. [29], and amounts below $6.82 \mathrm{mg} \cdot 100 \mathrm{~g}^{-1}$ f.w. were recorded by Jedrszczyk and Ambroszczyk [30] with the organically fertilized tomato cultivar Mieszko $F_{1}$. As previously reported, the lycopene concentration of tomato fruits can vary with the cultivar, the environmental factors, and the soil's biological status [31-33]. In the present experiment, the fertilization type and the irrigation regime had a significant influence on the lycopene concentration of tomato fruits (Table 3). 
Regardless of the wavelength used for the determination, the lycopene concentration of the tomato fruits that were organically fertilized was significantly higher as compared with the tomato fruits that were chemically fertilized. Regarding the irrigation regime, significant differences were observed only for the lycopene concentration measured at $502 \mathrm{~nm}$. In this case, the lycopene concentration recorded in the tomato fruits watered with $300 \mathrm{~m}^{3} \cdot \mathrm{ha}^{-1}$ was significantly higher as compared with $200 \mathrm{~m}^{3} \cdot \mathrm{ha}^{-1}$ water. No significant differences were recorded between the cultivars.

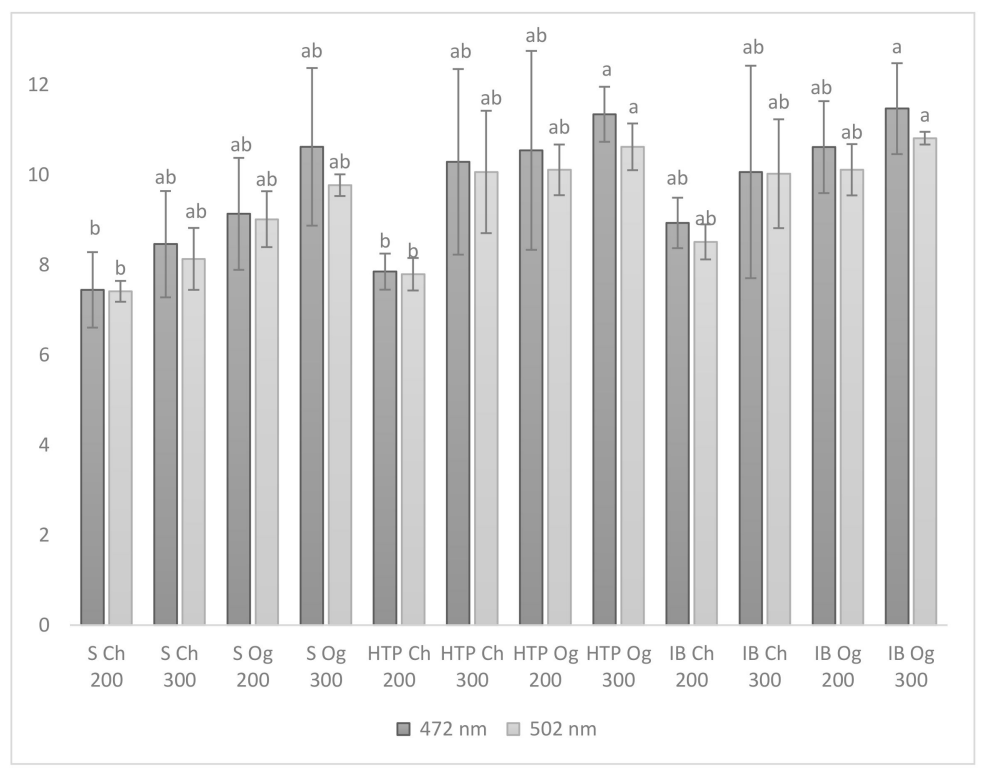

Figure 1. Influence of cultivar, fertilization type, and irrigation regime on the lycopene concentration at 472 and $502 \mathrm{~nm}$ (mg.100 $\mathrm{g}^{-1}$ f.w.). S-Siriana $\mathrm{F}_{1} ; \mathrm{H}-\mathrm{HTP} \mathrm{F}_{1}$; IB-Inima de Bou; Ch-chemical; Og—organic; $200-200 \mathrm{~m}^{3}$ water $\cdot \mathrm{ha}^{-1} ; 300-300 \mathrm{~m}^{3}$ water $\cdot \mathrm{ha}^{-1}$. Different letters represent significant differences between the treatments, according to Tukey's test at $p \leq 0.05$.

Table 3. Influence of the cultivar, fertilization type, and irrigation regime on the lycopene, polyphenols, and antioxidant activity.

\begin{tabular}{|c|c|c|c|c|}
\hline \multirow{2}{*}{ Treatment } & \multicolumn{2}{|c|}{ Lycopene (mg.100 g ${ }^{-1}$ f.w.) } & \multirow{2}{*}{$\begin{array}{l}\text { Polyphenols } \\
\text { (mg-100 g }{ }^{-1} \text { f.w.) }\end{array}$} & \multirow{2}{*}{$\begin{array}{l}\text { Antioxidant Activity } \\
\left(\mathrm{mmol} \text { Trol } \cdot 100 \mathrm{~g}^{-1} \text { f.w. }\right)\end{array}$} \\
\hline & $472 \mathrm{~nm}$ & $502 \mathrm{~nm}$ & & \\
\hline \multicolumn{5}{|l|}{ Cultivar } \\
\hline Siriana $F_{1}(S)$ & $8.91 \pm 0.55$ & $8.58 \pm 0.14$ & $1584.95 \pm 70.11 b$ & $78.09 \pm 3.91 \mathrm{a}$ \\
\hline $\mathrm{HTP} \mathrm{F}_{1}(\mathrm{H})$ & $10.01 \pm 0.15$ & $9.70 \pm 0.64$ & $1706.53 \pm 1.52 \mathrm{ab}$ & $57.97 \pm 0.31 b$ \\
\hline Inima de Bou (IB) & $\begin{array}{c}10.27 \pm 0.70 \\
\mathrm{~ns}\end{array}$ & $\begin{array}{c}9.85 \pm 0.14 \\
\mathrm{~ns}\end{array}$ & $1801.71 \pm 34.83 \mathrm{a}$ & $78.80 \pm 0.99 a$ \\
\hline \multicolumn{5}{|l|}{ Fertilization } \\
\hline Chemical (Ch) & $8.84 \pm 0.61 b$ & $8.66 \pm 0.24 b$ & $1702.24 \pm 61.83$ & $68.38 \pm 1.80 \mathrm{~b}$ \\
\hline Organic (Og) & $10.62 \pm 0.21 \mathrm{a}$ & $10.10 \pm 0.21 \mathrm{a}$ & $\begin{array}{c}1693.22 \pm 20.27 \\
\text { ns }\end{array}$ & $74.87 \pm 1.36 \mathrm{a}$ \\
\hline \multicolumn{5}{|l|}{ Irrigation regime } \\
\hline $200 \mathrm{~m}^{3} \cdot \mathrm{ha}^{-1}$ & $9.09 \pm 0.20$ & $8.83 \pm 0.12 b$ & $1736.72 \pm 44.28$ & $70.98 \pm 1.76$ \\
\hline $300 \mathrm{~m}^{3} \cdot \mathrm{ha}^{-1}$ & $\begin{array}{c}10.38 \pm 0.74 \\
\text { ns }\end{array}$ & $9.93 \pm 0.22 \mathrm{a}$ & $\begin{array}{c}1658.74 \pm 62.28 \\
\text { ns }\end{array}$ & $\begin{array}{c}72.26 \pm 2.80 \\
\text { ns }\end{array}$ \\
\hline
\end{tabular}

$\mathrm{S}$-Siriana $\mathrm{F}_{1} ; \mathrm{H}-\mathrm{HTP}_{1} ; \mathrm{IB}$-Inima de Bou; $\mathrm{Ch}$-chemical; Og—organic; 200 -200 $\mathrm{m}^{3} \cdot \mathrm{ha}^{-1}$ (67\% ET replenishment); $300-300 \mathrm{~m}^{3} \cdot \mathrm{ha}^{-1}(100 \%$ ET replenishment); ns: not statistically significant. Within each column and within each experimental factor, different letters mean treatments differ significantly according to Tukey's test at $p \leq 0.05$

The polyphenol concentration was highest in the cultivar IB, which did not significantly differ from HTP F1, whereas S and IB showed the highest antioxidant activity. The latter was higher under organic management compared to the conventional one. In a previous investigation [34], the organic 
crop system elicited significantly higher contents of apigenin acetylhexoside, caffeic acid hexoside I, and phloretin dihexoside out of the 30 polyphenols detected in tomato fruits, though the content of polyphenols was also dependent on the cultivar.

No significant differences were recorded for the rest of the treatments. Regarding the main effects of cultivar, fertilization type, and irrigation regime on the polyphenol concentration, the cultivar had a statistically significant main effect on the synthesis of polyphenols (Table 3). Their concentration in the tomato fruits of the IB cultivar was significantly higher as compared to S or H cultivars. No significant differences were recorded for the polyphenols between the two fertilization types or irrigation regimes (Table 3). The antioxidant activity was significantly influenced by both cultivar and fertilization type (Table 3).

The results regarding the influence of the three experimental factors applied on the polyphenols and antioxidant capacity of tomato fruits are presented in Table 4.

Table 4. Interaction between cultivar, fertilization type, and irrigation regime on total polyphenol concentration and antioxidant capacity.

\begin{tabular}{|c|c|c|}
\hline Treatment & Polyphenols (mg.100 $\mathrm{g}^{-1}$ f.w.) & Antioxidant Activity (mmol Trol $\cdot 100 \mathrm{~g}^{-1}$ f.w.) \\
\hline S Ch 200 & $1623.26 \pm 135.06 \mathrm{ab}$ & $77.94 \pm 6.48 \mathrm{ab}$ \\
\hline S Ch 300 & $1724.12 \pm 151.78 \mathrm{ab}$ & $71.98 \pm 6.34 \mathrm{ab}$ \\
\hline S Og 200 & $1869.19 \pm 146.27 \mathrm{a}$ & $82.81 \pm 6.48 \mathrm{ab}$ \\
\hline S Og 300 & $1423.25 \pm 152.14 b$ & $79.63 \pm 10.79 \mathrm{ab}$ \\
\hline HTP Ch 200 & $1609.27 \pm 89.91 \mathrm{ab}$ & $52.14 \pm 2.91 b$ \\
\hline HTP Ch 300 & $1686.29 \pm 142.13 \mathrm{ab}$ & $54.84 \pm 4.62 \mathrm{ab}$ \\
\hline HTP Og 200 & $1724.27 \pm 118.01 \mathrm{ab}$ & $61.45 \pm 4.21 \mathrm{ab}$ \\
\hline HTP Og 300 & $1806.28 \pm 88.81 \mathrm{ab}$ & $63.46 \pm 3.12 \mathrm{ab}$ \\
\hline IB Ch 200 & $1826.26 \pm 211.86 \mathrm{ab}$ & $65.24 \pm 7.57 \mathrm{ab}$ \\
\hline IB Ch 300 & $1744.23 \pm 211.59 \mathrm{ab}$ & $88.11 \pm 10.69 \mathrm{a}$ \\
\hline IB Og 200 & $1768.08 \pm 100.29 \mathrm{ab}$ & $86.31 \pm 4.90 \mathrm{a}$ \\
\hline IB Og 300 & $1868.29 \pm 110.09 \mathrm{a}$ & $75.54 \pm 4.45 \mathrm{ab}$ \\
\hline
\end{tabular}

S-Siriana $\mathrm{F}_{1} ; \mathrm{H}-\mathrm{HTP}_{1} ; \mathrm{IB}$-Inima de Bou; $\mathrm{Ch}$-chemical; Og—organic; $200-200 \mathrm{~m}^{3} \cdot \mathrm{ha}^{-1}$ (67\% ET replenishment); $300-300 \mathrm{~m}^{3} \cdot \mathrm{ha}^{-1}(100 \%$ ET replenishment). Within each column, different letters mean significant differences between the treatments, according to Tukey's test at $p \leq 0.05$.

The total polyphenol concentration was significantly higher $(31.3 \%)$ in the fruits of organically fertilized Siriana $\mathrm{F}_{1}$ watered with $200 \mathrm{~m}^{3} \cdot \mathrm{ha}^{-1}$ compared to the same organically fertilized cultivar irrigated with $300 \mathrm{~m}^{3} \cdot \mathrm{ha}^{-1}$. However, the S Og 300 treatment led to a lower polyphenol level than the fruits of the organically fertilized cultivar IB irrigated with the same amount of water (Table 4).

The best antioxidant activity was recorded for IB and S cultivars as compared with the $\mathrm{H}$ cultivar. However, the results regarding the interactions between cultivar, fertilization type, and irrigation regime showed significant differences only for the IB cultivar that was chemically fertilized with a 100\% evapotranspiration replenishment or organically fertilized with a $67 \%$ evapotranspiration replenishment as compared to the cultivar HTP that was chemically fertilized and watered according to $67 \%$ replenishment. Similar values of the antioxidant activity were obtained in previous studies on tomato [6,29] and in related species such as red pepper [35]. Regarding fertilization type, organic fertilization gave a significantly higher antioxidant activity compared to chemical fertilization (Table 3).

\subsection{Fruit Elemental Composition}

The main effects of the experimental factors on the macroelement concentration in tomato fruits are presented in Table 5 . The results showed that $\mathrm{Mg}$ and $\mathrm{K}$ were significantly influenced by the fertilization type only. For both macroelements, Ch fertilization enhanced their concentration in the tomato fruits as compared to $\mathrm{Og}$ fertilization. The highest $\mathrm{P}$ concentration was affected by both cultivar and fertilization type. For $\mathrm{S}$ and $\mathrm{H}$ cultivars, the $\mathrm{P}$ concentration was significantly higher as compared with the IB cultivar. Regarding fertilization type, the $\mathrm{Ch}$ treatment showed a $\mathrm{P}$ concentration in the 
fruits that was statistically higher than $\mathrm{Og}$ fertilization. Ca was significantly affected by all the factors applied (cultivar, fertilization, irrigation regime). The cultivar Siriana $\mathrm{F}_{1}$ showed a higher $\mathrm{Ca}$ value than IB and HTP $\mathrm{F}_{1}$. As in the case of $\mathrm{Mg}, \mathrm{P}$, and $\mathrm{K}$, the $\mathrm{Ch}$ fertilization enhanced the Ca concentration in the tomato fruits, significant differences being recorded as compared to $\mathrm{Og}$ fertilization. Additionally, it was observed that with $67 \%$ evapotranspiration replenishment $\left(200 \mathrm{~m}^{3} \cdot \mathrm{ha}^{-1}\right)$, the Ca concentration was significantly higher as compared with $100 \%$ evapotranspiration replenishment $\left(300 \mathrm{~m}^{3} \cdot \mathrm{ha}^{-1}\right)$.

Table 5. Influence of cultivar, fertilization type, and irrigation regime on macroelements concentration in tomato fruits.

\begin{tabular}{|c|c|c|c|c|}
\hline Treatment & $\operatorname{Mg}\left(\mathrm{mg} \cdot 100 \mathrm{~g}^{-1}\right.$ f.w.) & $P$ (mg.100 g ${ }^{-1}$ f.w.) & $K\left(\mathrm{mg} \cdot 100 \mathrm{~g}^{-1}\right.$ f.w.) & Ca (mg.100 $\mathrm{g}^{-1}$ f.w.) \\
\hline \multicolumn{5}{|l|}{ Cultivar } \\
\hline Siriana $F_{1}(S)$ & $11.84 \pm 0.79$ & $10.82 \pm 0.26 \mathrm{a}$ & $227.42 \pm 15.03$ & $12.32 \pm 0.29 a$ \\
\hline $\mathrm{HTP} \mathrm{F}_{1}(\mathrm{H})$ & $9.76 \pm 0.25$ & $12.44 \pm 0.22 \mathrm{a}$ & $217.41 \pm 4.11$ & $10.41 \pm 0.28 b$ \\
\hline Inima de Bou (IB) & $\begin{array}{c}10.30 \pm 0.48 \\
\mathrm{~ns}\end{array}$ & $8.51 \pm 0.57 \mathrm{~b}$ & $\begin{array}{c}209.50 \pm 2.13 \\
n s\end{array}$ & $5.88 \pm 0.39 c$ \\
\hline \multicolumn{5}{|l|}{ Fertilization } \\
\hline Chemical (Ch) & $11.71 \pm 0.22 \mathrm{a}$ & $13.03 \pm 0.57 \mathrm{a}$ & $230.61 \pm 7.46 \mathrm{a}$ & $11.99 \pm 0.05 a$ \\
\hline Organic (Og) & $9.55 \pm 0.51 b$ & $8.14 \pm 0.15 b$ & $205.61 \pm 4.71 \mathrm{~b}$ & $7.08 \pm 0.30 \mathrm{~b}$ \\
\hline \multicolumn{5}{|l|}{ Irrigation regime } \\
\hline $200 \mathrm{~m}^{3} \cdot \mathrm{ha}^{-1}$ & $11.07 \pm 0.19$ & $11.36 \pm 0.60$ & $225.61 \pm 9.10$ & $10.07 \pm 0.13 a$ \\
\hline \multirow[t]{2}{*}{$300 \mathrm{~m}^{3} \cdot \mathrm{ha}^{-1}$} & $10.19 \pm 0.53$ & $9.81 \pm 0.32$ & $210.61 \pm 1.49$ & $9.00 \pm 0.33 b$ \\
\hline & ns & ns & ns & \\
\hline
\end{tabular}

The results of the interaction between the cultivar, fertilization type, and irrigation regime on the macroelement concentration (magnesium- $-\mathrm{Mg}$, phosphorus $-\mathrm{P}$, potassium $-\mathrm{K}$, calcium-Ca) in tomato fruits are presented in Table 6.

Table 6. Interaction between cultivar, fertilization type, and irrigation regime on macroelements concentration in tomato fruits.

\begin{tabular}{|c|c|c|c|c|}
\hline Treatment & $\operatorname{Mg}\left(\mathrm{mg} \cdot 100 \mathrm{~g}^{-1}\right.$ f.w.) & $P$ (mg.100 g ${ }^{-1}$ f.w.) & $K\left(\mathrm{mg} \cdot 100 \mathrm{~g}^{-1}\right.$ f.w.) & Ca (mg.100 g ${ }^{-1}$ f.w.) \\
\hline S Ch 200 & $13.10 \pm 1.04 \mathrm{a}$ & $14.33 \pm 0.79 \mathrm{ab}$ & $247.33 \pm 21.67$ & $15.93 \pm 1.34 \mathrm{a}$ \\
\hline SCh 300 & $12.10 \pm 1.66 \mathrm{ab}$ & $13.17 \pm 1.12 \mathrm{ac}$ & $238.33 \pm 18.55$ & $14.20 \pm 0.96 \mathrm{ab}$ \\
\hline S Og 200 & $11.60 \pm 0.64 \mathrm{ab}$ & $8.30 \pm 0.59 \mathrm{ce}$ & $219.00 \pm 29.61$ & $9.63 \pm 0.46 b c$ \\
\hline S Og 300 & $10.50 \pm 0.90 \mathrm{ab}$ & $7.47 \pm 0.38 \mathrm{de}$ & $205.00 \pm 11.68$ & $9.50 \pm 1.10 c$ \\
\hline HTP Ch 200 & $11.40 \pm 0.79 \mathrm{ab}$ & $15.67 \pm 1.82 \mathrm{a}$ & $227.00 \pm 19.08$ & $15.00 \pm 1.82 \mathrm{a}$ \\
\hline HTP Ch 300 & $10.60 \pm 0.52 \mathrm{ab}$ & $13.90 \pm 1.70 \mathrm{ab}$ & $217.00 \pm 14.93$ & $14.20 \pm 0.79 \mathrm{ab}$ \\
\hline HTP Og 200 & $9.50 \pm 1.10 \mathrm{ab}$ & $11.70 \pm 0.64 \mathrm{ad}$ & $215.67 \pm 18.22$ & $7.83 \pm 0.65 \mathrm{~cd}$ \\
\hline HTP Og 300 & $7.50 \pm 0.89 \mathrm{~b}$ & $8.47 \pm 0.49$ cde & $210.00 \pm 14.36$ & $4.60 \pm 0.40 \mathrm{~d}$ \\
\hline IB Ch 200 & $11.60 \pm 0.95 \mathrm{ab}$ & $11.63 \pm 1.02 \mathrm{ad}$ & $248.67 \pm 12.14$ & $6.50 \pm 0.49 \mathrm{~cd}$ \\
\hline IB Ch 300 & $11.40 \pm 1.00 \mathrm{ab}$ & $9.50 \pm 0.72$ be & $205.33 \pm 23.84$ & $6.10 \pm 0.80 \mathrm{~cd}$ \\
\hline IB Og 200 & $9.20 \pm 0.72 \mathrm{ab}$ & $6.50 \pm 0.90 \mathrm{e}$ & $196.00 \pm 23.69$ & $5.50 \pm 0.31 \mathrm{~cd}$ \\
\hline IB Og 300 & $9.00 \pm 1.21 \mathrm{ab}$ & $6.40 \pm 0.36 \mathrm{e}$ & $\begin{array}{c}188.00 \pm 10.79 \\
\text { n.s. }\end{array}$ & $5.40 \pm 0.45 \mathrm{~cd}$ \\
\hline
\end{tabular}

S-Siriana $\mathrm{F}_{1} ; \mathrm{H}$ - $\mathrm{HTP} \mathrm{F}_{1} ; \mathrm{IB}$-Inima de Bou; $\mathrm{Ch}$-chemical; Og—organic; 200-200 $\mathrm{m}^{3} \cdot \mathrm{ha}^{-1}$ (67\% ET replenishment); $300-300 \mathrm{~m}^{3} \cdot \mathrm{ha}^{-1}(100 \%$ ET replenishment); ns: not statistically significant. Within each column, different letters mean significant differences between the treatments, according to Tukey's test at $p \leq 0.05$.

The $\mathrm{Mg}$ concentration in tomato fruits showed a significant increase of $74.7 \%$ over cultivar HTP Og 300 to S Ch 200.

Chemical fertilization usually resulted in a higher P concentration in tomato fruits compared to organic nutrition, suggesting an easier plant uptake of this element from chemical fertilizers in greenhouses. In particular, the $\mathrm{P}$ concentration was $80 \%$ higher in the cultivar $\mathrm{HTP} \mathrm{F}_{1} \mathrm{x}$ organic fertilization $\times 67 \%$ ET replenishment compared to the cultivar IB under the same fertilization type and irrigation regime. 
The element found at the highest concentrations in the tomato fruits was $\mathrm{K}$. The concentration ranged from $188.00 \mathrm{mg} \cdot 100 \mathrm{~g}^{-1}$ f.w. for IB Og 300 to $248.67 \mathrm{mg} \cdot 100 \mathrm{~g}^{-1}$ f.w. for IB Ch 200 . K was not significantly affected by the interaction between the three experimental factors (Table 6). However, the highest concentration of $\mathrm{K}$ was registered for $\mathrm{Ch}$ fertilization (Table 5). In previous research [26], the higher effectiveness of chemical fertilization and moderate irrigation regime on potassium content was also reported.

Calcium is a major element in plants, but it is also very important for human health due to its significant concentration in the bones $[6,15,16]$. In our study, the Ca concentration was 2-3 times lower in the fruits of cultivar HTP $F_{1}$ under organic fertilization with $200 \mathrm{~m}^{3} \cdot \mathrm{ha}^{-1}$ and $300 \mathrm{~m}^{3} \cdot \mathrm{ha}^{-1}$ irrigation regimes than the $\mathrm{Ch}$ treatment.

Likewise, chemical fertilization also elicited a higher accumulation of this element in the tomato fruits of cultivar Siriana $F_{1}$ (Table 5). Significant differences were also seen between cultivars Siriana $\mathrm{F}_{1}$ and HTP, chemically fertilized, and cultivar IB, chemically or organic fertilized, regardless of the irrigation regime.

Notably, the mineral concentration recorded in the present study is much higher compared to previous investigations carried out on tomato $[27,36]$. Indeed, the mineral concentration is closely dependent on the crop system, i.e., the soil and environmental conditions, the genotype, and the farming practices.

The main effects of the experimental factors on the microelement concentration in tomato fruits are presented in Table 7. In this respect, a significant influence of the cultivar was recorded for $\mathrm{Mn}, \mathrm{Zn}$, $\mathrm{Ni}$, and $\mathrm{Pb}$ : $\mathrm{Mn}$ showed the lowest concentration in Siriana $\mathrm{F}_{1}$, whereas the other two cultivars did not differ from each other; the opposite trend was recorded for $\mathrm{Pb}$. For $\mathrm{Zn}$, the lowest concentration was recorded for IB and the highest for Siriana $F_{1}$ and HTP $F_{1}$ cultivars, while for Ni, the lowest concentration was found in the tomato fruits of HTP $\mathrm{F}_{1}$ and the highest in Siriana $\mathrm{F}_{1}$ and Inima de Bou.

Significant influence of the fertilization type on microelements and heavy metal concentrations were found for $\mathrm{Cu}, \mathrm{Mn}, \mathrm{Ni}$, and $\mathrm{Pb}$. For all these elements, the lowest values were recorded for $\mathrm{Og}$ fertilization as compared to $\mathrm{Ch}$ fertilization. No significant influence of the fertilization type was observed for $\mathrm{Fe}, \mathrm{Zn}$, and $\mathrm{Cr}$ (Table 7).

The irrigation regime had a significant influence on $\mathrm{Pb}$ only, the $100 \%$ evapotranspiration replenishment $\left(300 \mathrm{~m}^{3} \cdot \mathrm{ha}^{-1}\right)$ giving the lowest concentration of this element in the tomato fruits.

In summary, $\mathrm{Cu}$ was influenced by the fertilization type only, $\mathrm{Mn}$ and $\mathrm{Ni}$ by cultivar and irrigation regime, $\mathrm{Pb}$ by all the factors taken into consideration, while $\mathrm{Fe}$ and $\mathrm{Cr}$ by none of them.

With regard to microelements (Table 8), the $\mathrm{Cu}$ concentration was not significantly affected by the interaction between the three experimental factors applied. However, the values were below the tolerance threshold relevant to this element. Slightly higher concentrations of $\mathrm{Cu}$ were detected in the tomato fruits obtained in the present experiment compared to previous investigations [35,37], probably due to the organic cultivation technology consisting of antifungal treatments based on $\mathrm{Cu}$.

No significant effect of the interaction between the three experimental factors applied was recorded on the Fe concentration in tomato fruits.

Mn was the least represented element in the tomato fruits, with the lowest concentration in cultivar Siriana $F_{1}$, supplied with organic fertilizer and irrigated with $300 \mathrm{~m}^{3} \cdot \mathrm{ha}^{-1}$, and a 2.94-fold higher level in HTP $F_{1}$ that was chemically fertilized under the $200 \mathrm{~m}^{3} \cdot \mathrm{ha}^{-1}$ irrigation regime.

The $\mathrm{Zn}$ concentration in the tomato fruits varied between 169 ppm for IB Og 300 interaction and 299 ppm for S Ch 200. Increased amounts of $\mathrm{Zn}$ were recorded for chemical fertilization, regardless of the cultivar or the irrigation regime, with slightly higher but not significant amounts for the irrigation with $200 \mathrm{~m}^{3} \cdot \mathrm{ha}^{-1}$ water. For IB Og 300, the Zn values registered were significantly lower compared with S Ch 200, but higher than those reported by Hura et al. [37] or Munteanu et al. [38]. 
Table 7. Influence of cultivar, fertilization type, and irrigation regime on microelement and heavy metal concentrations in tomato fruits.

\begin{tabular}{|c|c|c|c|c|c|c|c|}
\hline Treatment & $\mathrm{Cu}$ (mg. kg ${ }^{-1}$ f.w.) & $\mathrm{Fe}\left(\mathrm{mg} \cdot \mathrm{kg}^{-1}\right.$ f.w.) & Mn (mg.kg ${ }^{-1}$ f.w.) & Zn (mg.kg ${ }^{-1}$ f.w.) & $\mathrm{Cr}$ (mg. kg ${ }^{-1}$ f.w.) & Ni (mg.kg ${ }^{-1}$ f.w.) & $\mathrm{Pb}$ (mg.kg-1 f.w.) \\
\hline Cultivar & & & & & & & \\
\hline Siriana $F_{1}(S)$ & $40.00 \pm 1.84$ & $57.74 \pm 0.85$ & $2.77 \pm 0.10 \mathrm{~b}$ & $252.50 \pm 16.49 a$ & $100.75 \pm 0.80$ & $65.00 \pm 1.31 \mathrm{a}$ & $62.00 \pm 4.18 \mathrm{a}$ \\
\hline $\mathrm{HTP}_{1}(\mathrm{H})$ & $36.50 \pm 0.44$ & $50.94 \pm 2.71$ & $4.82 \pm 0.06 \mathrm{a}$ & $223.00 \pm 2.61 \mathrm{a}$ & $91.00 \pm 1.21$ & $40.00 \pm 0.89 b$ & $35.25 \pm 0.97 b$ \\
\hline Inima de Bou (IB) & $\begin{array}{c}39.50 \pm 0.75 \\
\mathrm{~ns}\end{array}$ & $\begin{array}{c}50.53 \pm 2.83 \\
\text { ns }\end{array}$ & $4.65 \pm 0.09 \mathrm{a}$ & $175.50 \pm 3.96 b$ & $\begin{array}{c}95.75 \pm 10.98 \\
\text { ns }\end{array}$ & $56.00 \pm 3.77 \mathrm{a}$ & $45.00 \pm 0.83 \mathrm{~b}$ \\
\hline Fertilization type & & & & & & & \\
\hline Chemical (Ch) & $42.33 \pm 0.50 \mathrm{a}$ & $55.82 \pm 3.22$ & $4.15 \pm 0.16 \mathrm{a}$ & $232.00 \pm 2.79$ & $101.67 \pm 3.53$ & $59.34 \pm 3.16 \mathrm{a}$ & $54.00 \pm 1.06 \mathrm{a}$ \\
\hline Organic $(\mathrm{Og})$ & $35.00 \pm 0.80 \mathrm{~b}$ & $\begin{array}{c}50.30 \pm 1.07 \\
\text { ns }\end{array}$ & $3.67 \pm 0.01 \mathrm{~b}$ & $\begin{array}{c}202.00 \pm 13.31 \\
\text { ns }\end{array}$ & $\begin{array}{c}90.00 \pm 5.20 \\
\mathrm{~ns}\end{array}$ & $48.00 \pm 0.76 b$ & $40.83 \pm 2.01 \mathrm{~b}$ \\
\hline Irrigation regime & & & & & & & \\
\hline $200 \mathrm{~m}^{3} \cdot \mathrm{ha}^{-1}$ & $39.34 \pm 1.22$ & $54.05 \pm 3.34$ & $4.00 \pm 0.14$ & $225.83 \pm 5.39$ & $98.00 \pm 1.14$ & $56.34 \pm 1.64$ & $50.67 \pm 1.35 \mathrm{a}$ \\
\hline $300 \mathrm{~m}^{3} \cdot \mathrm{ha}^{-1}$ & $\begin{array}{c}38.00 \pm 1.53 \\
\mathrm{~ns}\end{array}$ & $\begin{array}{c}52.07 \pm 1.10 \\
\text { ns }\end{array}$ & $\begin{array}{c}3.82 \pm 0.13 \\
\text { ns }\end{array}$ & $\begin{array}{c}208.17 \pm 10.38 \\
\text { ns }\end{array}$ & $\begin{array}{c}93.66 \pm 7.13 \\
\mathrm{~ns}\end{array}$ & $\begin{array}{c}51.00 \pm 2.30 \\
\mathrm{~ns}\end{array}$ & $44.16 \pm 1.62 b$ \\
\hline
\end{tabular}

Table 8. Interaction between cultivar, fertilization type, and irrigation regime on microelement and heavy metal concentrations in tomato fruits.

\begin{tabular}{|c|c|c|c|c|c|c|c|}
\hline Treatment & $\mathrm{Cu}$ (mg.kg-1 f.w.) & $\mathrm{Fe}\left(\mathrm{mg} \cdot \mathrm{kg}^{-1}\right.$ f.w.) & Mn (mg.kg-1 f.w.) & Zn (mg.kg ${ }^{-1}$ f.w.) & $\mathrm{Cr}$ (mg.kg ${ }^{-1}$ f.w.) & $\mathrm{Ni}\left(\mathrm{mg} \cdot \mathrm{kg}^{-1}\right.$ f.w.) & $\mathrm{Pb}$ (mg.kg ${ }^{-1}$ f.w.) \\
\hline S Ch 200 & $47 \pm 3.91$ & $65.1 \pm 3.7$ & $2.9 \pm 0.26 b c$ & $299 \pm 23.39 a$ & $105 \pm 8.2$ & $90 \pm 5.03 a$ & $77 \pm 6.03 \mathrm{a}$ \\
\hline S Ch 300 & $46 \pm 4.05$ & $61.9 \pm 5.2$ & $2.6 \pm 0.23 c$ & $253 \pm 34.27 \mathrm{ab}$ & $103 \pm 14.0$ & $67 \pm 5.65 \mathrm{ab}$ & $75 \pm 10.16 \mathrm{ab}$ \\
\hline S Og 200 & $35 \pm 2.74$ & $52.4 \pm 3.6$ & $1.9 \pm 0.15 c$ & $232 \pm 12.96 \mathrm{ab}$ & $99 \pm 5.5$ & $53 \pm 3.63 \mathrm{bc}$ & $52 \pm 2.90 \mathrm{bc}$ \\
\hline S Og 300 & $32 \pm 4.33$ & $51.5 \pm 2.5$ & $1.7 \pm 0.25 c$ & $226 \pm 19.05 \mathrm{ab}$ & $96 \pm 8.1$ & $50 \pm 2.46 \mathrm{bc}$ & $44 \pm 3.71 \mathrm{~cd}$ \\
\hline HTP Ch 200 & $39 \pm 2.18$ & $53.1 \pm 6.2$ & $5.0 \pm 0.31 \mathrm{a}$ & $253 \pm 17.31 \mathrm{ab}$ & $98 \pm 6.7$ & $42 \pm 4.87 \mathrm{c}$ & $43 \pm 2.94 \mathrm{~cd}$ \\
\hline HTP Ch 300 & $38 \pm 3.20$ & $51.7 \pm 6.3$ & $4.9 \pm 0.42 \mathrm{a}$ & $226 \pm 11.11 \mathrm{ab}$ & $92 \pm 4.5$ & $41 \pm 4.97 \mathrm{c}$ & $39 \pm 1.91 \mathrm{~cd}$ \\
\hline HTP Og 200 & $35 \pm 2.40$ & $50.9 \pm 4.5$ & $4.8 \pm 0.32 \mathrm{a}$ & $218 \pm 25.29 \mathrm{ab}$ & $88 \pm 7.3$ & $39 \pm 3.24 c$ & $32 \pm 3.71 \mathrm{~cd}$ \\
\hline HTP Og 300 & $34 \pm 1.67$ & $48.1 \pm 3.8$ & $4.6 \pm 0.23 \mathrm{ab}$ & $195 \pm 10.89 \mathrm{~b}$ & $86 \pm 7.6$ & $38 \pm 3.34 \mathrm{c}$ & $27 \pm 3.28 \mathrm{~d}$ \\
\hline IB Ch 200 & $43 \pm 4.99$ & $52.4 \pm 7.1$ & $4.9 \pm 0.57 \mathrm{a}$ & $181 \pm 15.26 b$ & $112 \pm 8.8$ & $59 \pm 4.62 \mathrm{bc}$ & $50 \pm 2.84 \mathrm{~cd}$ \\
\hline IB Ch 300 & $41 \pm 4.97$ & $50.8 \pm 2.8$ & $4.7 \pm 0.58 \mathrm{a}$ & $180 \pm 12.32 b$ & $100 \pm 13.5$ & $57 \pm 7.72 \mathrm{bc}$ & $40 \pm 3.33 \mathrm{~cd}$ \\
\hline IB Og 200 & $37 \pm 2.09$ & $50.4 \pm 4.2$ & $4.5 \pm 0.26 \mathrm{ab}$ & $172 \pm 8.46 \mathrm{~b}$ & $86 \pm 4.8$ & $55 \pm 3.07 \mathrm{bc}$ & $50 \pm 4.40 \mathrm{~cd}$ \\
\hline IB Og 300 & $\begin{array}{c}37 \pm 2.18 \\
\text { n.s. }\end{array}$ & $\begin{array}{c}48.5 \pm 3.3 \\
\text { n.s. }\end{array}$ & $4.5 \pm 0.25 \mathrm{ab}$ & $169 \pm 19.61 b$ & $\begin{array}{c}85 \pm 7.2 \\
\text { n.s. }\end{array}$ & $53 \pm 4.47 c$ & $40 \pm 3.13 \mathrm{~cd}$ \\
\hline
\end{tabular}

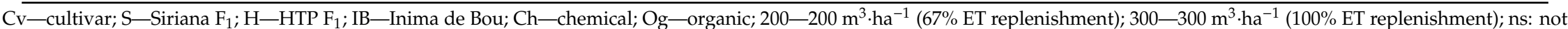
statistically significant. Within each column, different letters mean significant differences between the treatments, according to Tukey's test at $p \leq 0.05$. 
With regard to mineral elements, Ordóñez-Santos et al. [39] reported that the micronutrients analyzed ( $\mathrm{Fe}, \mathrm{Zn}, \mathrm{Mn}$, and $\mathrm{Cu}$ ) were affected by the genotype, whereas no significant differences were recorded between organic and conventional crop systems, taking into account the efficient soil fertility management. However, Mn was significantly affected by the interaction between the crop system and the cultivar. In other research [40], the cropping method showed a significant interaction with the cultivar on macro- and microelements. In particular, the microelements were more affected by cultivar and the macroelements the cropping method, and only $\mathrm{K}$ and $\mathrm{Mg}$ gave a remarkable contribution to the mineral intake from tomato fruits.

Among the heavy metals, the $\mathrm{Cr}$ concentration of the tomato fruits was not significantly affected by the interaction between the three experimental factors applied. Compared to other tomato cultivars, the $\mathrm{Cr}$ concentration recorded in the fruits of the varieties examined in the present trial was higher, especially for the chemically fertilized plants [21].

The $\mathrm{Ni}$ and $\mathrm{Pb}$ concentrations in the tomato fruits of Siriana $\mathrm{F}_{1}$ that was chemically fertilized and irrigated according to the $67 \%$ evapotranspiration replenishment were 2.37-fold and 2.85-fold higher, respectively, compared to those measured in $\mathrm{HTP} \mathrm{F}_{1}$ under organic fertilization and $100 \%$ replenishment. In cultivar Siriana $\mathrm{F}_{1}$, chemical fertilization elicited a higher fruit $\mathrm{Ni}$ and $\mathrm{Pb}$ accumulation compared to both organic nutrition and the same nutrition type applied to these other two cultivars, suggesting an important genotype role in the absorption of this element. Lower $\mathrm{Pb}$ concentrations in tomato fruits obtained in greenhouses were reported by Munteanu et al. [38].

However, in all the experimental treatments, the concentration of each heavy metal in tomato fruit did not overcome the related acceptance threshold: $\mathrm{Cr}=150 ; \mathrm{Ni}=100 ; \mathrm{Pb}=50$ [38].

Similar results regarding the microelement concentrations in the tomato fruits were obtained by Wang et al. [25] by using a moderate water regime in protected environment conditions.

The higher fruit concentrations of some heavy metals elicited by chemical fertilization, compared to organic fertilization, show that the former type favors a higher plant uptake of potentially toxic elements. Therefore, the chemical fertilizer application should be accurately monitored in order to prevent the excessive accumulation of heavy metals in tomato fruits.

\section{Materials and Methods}

\subsection{Plant Material and Growth Conditions}

The experiment was done at the University of Agricultural Sciences and Veterinary Medicine (UASMV) of Iasi, Romania $\left(47^{\circ} 19^{\prime} 25^{\prime \prime} \mathrm{N}, 27^{\circ} 54^{\prime} 99^{\prime \prime} \mathrm{E}, 150 \mathrm{~m}\right.$ a.s.l), at the experimental station in a $400 \mathrm{~m}^{2}$ tunnel. The study was conducted over two years, 2018 and 2019, starting from mid-April each year. During the experiment period, the mean temperature was $18.4^{\circ} \mathrm{C}$ in 2018 and $18.3^{\circ} \mathrm{C}$ in 2019 . The sunlight was $244 \mathrm{~h}$ in 2018 and $213 \mathrm{~h}$ in 2019 , with a relative humidity that varied between $67 \%$ to $70 \%$. Tomato crop was preceded by runner beans on the soil used in the present investigation. The soil was alluvial cambic chernozem soil with the following characteristics: $\mathrm{pH} 7.2 ; 3.2 \%$ organic matter; $31 \%$ clay; $28 \mathrm{mg} \cdot \mathrm{kg}^{-1} \mathrm{~N}, 1.83 \% \mathrm{~K}_{2} \mathrm{O} ; 1.13 \% \mathrm{CaO} ; 0.19 \% \mathrm{P}_{2} \mathrm{O}_{5} ; 0.16 \% \mathrm{MgO} ; 0.46 \% \mathrm{Na}_{2} \mathrm{O} ; 3.96 \% \mathrm{Fe}_{2} \mathrm{O}_{3}$; $0.11 \% \mathrm{MnO} ; 49 \mathrm{ppm} \mathrm{Cu} ; 103 \mathrm{ppm} \mathrm{Zn;} \mathrm{EC} 416 \mu \mathrm{S} \cdot \mathrm{cm}^{-1}$. The soil was not subjected to any fumigation or pesticide treatment.

The experimental protocol was based on the comparison between two irrigation regimes in factorial combination with two fertilization types and three cultivars by using a split-plot design with three replications. The irrigation regime was assigned to the main plot, the fertilization type to the subplot, and the cultivar to the sub-subplot. The experimental unit surface area was $3.6 \mathrm{~m}^{2}\left(0.30 \mathrm{~m}^{2}\right.$ nutritive surface for each plant), including 12 tomato plants planted on beds with $1 \mathrm{~m}$ between rows and $0.3 \mathrm{~m}$ between plants per row.

The two irrigation regimes were based on the replenishment of $67 \%$ or $100 \%$ of ET [41], i.e., on the two watering volumes of 200 and $300 \mathrm{~m}^{3} \cdot \mathrm{ha}^{-1}$ at each irrigation, respectively. Tomato plants were 
irrigated 26 times over the whole crop season (as an average of the two crop seasons), corresponding to $67 \%$ or $100 \%$ crop evapotranspiration, respectively.

The two fertilization types consisted of the application of chemical fertilizer (Cristaland, NPK 16-16-16 by MsBiotech, Termoli, Italy) or organic fertilizer (Orgevit ${ }^{\circledR}$ by MeMon BV, Arnhem, The Netherlands). The organic fertilizer is a product based on chicken manure with the following characteristics: $\mathrm{pH} 7$, $4 \% \mathrm{~N}, 2.5 \% \mathrm{P}_{2} \mathrm{O}_{5}, 2.3 \% \mathrm{~K}_{2} \mathrm{O}, 1 \% \mathrm{MgO}, 0.02 \% \mathrm{Fe}, 0.01 \% \mathrm{Mn}, 0.01 \% \mathrm{~B}, 0.01 \% \mathrm{Zn}, 0.001 \% \mathrm{Cu}$, and $0.001 \%$ Mo. The fertilizers were applied to the soil at a dose of $800 \mathrm{~kg} \mathrm{ha}^{-1}$ for the chemical treatment and $4500 \mathrm{~kg} \mathrm{ha}^{-1}$ for the organic treatment. Both fertilizers were applied three times as follows: $50 \%$ of the total amount in coincidence with the final soil preparation prior to planting; $25 \%$ when the first fruit of the first cluster reached a 1-cm diameter; the last dose $(25 \%)$ when the first fruit of the third cluster reached a $1-\mathrm{cm}$ diameter. The doses of fertilizers were calculated by taking into account the following: the chemical composition of each formulate; that $60 \%$ of $\mathrm{N}, \mathrm{P}_{2} \mathrm{O}_{5}$, and $\mathrm{K}_{2} \mathrm{O}$ contents of the Og (Organic) fertilizer is available for plant assimilation in the year of application; $15 \%$ of nitrogen leaching is expected upon the chemical fertilizer supply, as the rate of nutrient release is much lower compared to simple nitrate fertilizers. In particular, the organic fertilizer was supplied three weeks before transplanting in order to allow the onset of the nitrification process, thus preventing the initial ammonium accumulation that may cause toxicity and enhancing the total nitrate amount released to plants over the entire crop cycle ET [42].

The three cultivars of Solanum lycopersicum were compared: Siriana $\mathrm{F}_{1}$ and Inima de Bou, released by the Vegetable Research Station Buzau, and HTP $F_{1}$ by the seed company Hazera. All of them produce round-shaped fruits with a smooth to waved surface.

The following growing practices were applied to all tomato plants: vertical training due to indeterminate growth, pruning above the fifth fruit truss, and treatments against pests with azadirachtin and against diseases with copper-based formulates.

The harvests began on 10 and 13 July and ended on 24 and 26 October in the first and second research years, respectively.

\subsection{Biometric and Yield Determinations}

In each plot and at each harvest, the number and weight of ripe fruits from any truss, as well as the mean fruit weight on random 20-fruit samples, were determined. The yields $\left(\mathrm{kg} \cdot \mathrm{ha}^{-1}\right)$ were calculated by using the following formula: (plants/ha $\times$ fruits/plant $\times$ average fruit weight)/1000 [29]. The plant heights $(\mathrm{cm})$ were measured after the last harvest in each experimental treatment.

\subsection{Sample Preparation}

In each plot, 20-ripe fruit random samples, each of them weighing 3000-3500 g, were collected from the different clusters for laboratory analyses.

The samples needed for biochemical analyses (lycopene and polyphenol contents, antioxidant capacity) were prepared as follows: fruits were cut into $1 \mathrm{~cm}$ fragments and dried on a Sanyo stove, type MOV-112F, at a temperature of $70{ }^{\circ} \mathrm{C}$ until constant weight. The samples were then ground into small fragments of $0.1-1 \mathrm{~mm}$.

\subsection{Lycopene Content}

The lycopene concentration of the tomato fruits was determined by using the solvent extraction method described by Butnariu and Giuchici [43]. Briefly, $0.6 \mathrm{~g}$ of fresh tomato puree was added in $5 \mathrm{~mL}$ of $0.05 \%(w / v)$ butylated hydroxytoluene (BHT) in acetone, $5 \mathrm{ml}$ of $95 \%$ ethanol, and $10 \mathrm{ml}$ of hexane and stirred for $15 \mathrm{~min}$ on ice. After stirring, $3 \mathrm{ml}$ of deionized water was added, and the samples were stirred for 5 more minutes on ice. For the phase separation, the samples were left at room temperature for $5 \mathrm{~min}$. The absorbance of the upper layer of hexane was measured at 472 and $502 \mathrm{~nm}$ by using hexane as a blank. 


\subsection{Polyphenol Content}

The concentration of different phenolic compounds in $70 \%$ ethanolic extracts was measured using an HPLC-MS method that allows the simultaneous detection of several phenolic compounds with a single column pass through [44]. The detection of the compounds was performed in both UV and MS modes [45]. The UV detector was set at $330 \mathrm{~nm}$ for $17.5 \mathrm{~min}$, and then at $370 \mathrm{~nm}$. The mobile phase was a binary gradient, with methanol and acetic acid $0.1 \%(v / v)$; the flow rate was $1 \mathrm{~mL} \cdot \mathrm{min}^{-1}$ and the injection volume was $5 \mu \mathrm{L}$ [46].

\subsection{Antioxidant Activity}

The neutralizing effect of the DPPH free radical was calculated at three different concentrations of methanol and ethanol extracts: $0.05 \mathrm{ml}$ of 10,5 , and $2.5 \mathrm{mg} \cdot \mathrm{mL}^{-1}$ extracts were mixed with $2.95 \mathrm{~mL}$ solution DPPH. After a 5-min reaction time, the absorption was measured at $420 \mathrm{~nm}$ using methanol as a blank. Approximately $10 \mathrm{~g}$ of finely ground plant material was extracted in $100 \mathrm{~mL}$ of $80 \%$ aqueous solution of ethanol at room temperature for $1 \mathrm{~h}$. The extracts were filtered, and the filters were left to evaporate in a dry environment. The percentage of free-radical scavenging activity was determined using the following formula: $100 \times(\mathrm{Ai}-\mathrm{Af}) / \mathrm{Ai}$, where $\mathrm{Ai}=$ the absorption before the addition of the tested extract; $\mathrm{Af}=$ the absorption value after 5 min reaction time.

$\mathrm{QE}$ was used as a positive control. At a concentration of $2.5 \mathrm{mM}, \mathrm{QE}$ was able to fully neutralize the level of DPPH radical used [47].

\subsection{Mineral Content}

The mineral concentration (macro- and microelements) of the tomato fruits was determined by using the atomic absorption spectrometry method. The fruits were first oven-dried at $105^{\circ} \mathrm{C}$ for $48 \mathrm{~h}$, and then samples of 0.5 and $1 \mathrm{~g}$ were digested [9]. The solutions obtained were analyzed by the atomic-absorption spectrometer Contra 300 (Analytik Jena, Göettingen, Germany).

\subsection{Statistical Analysis of the Data}

The experimental results are expressed as means \pm SD. The data were statistically processed by three-way ANOVA upon verifying the normality through the Shapiro-Wilk test, and Tukey's test was performed for mean separation at $p \leq 0.05$, using SPSS software version 21 (IBM Microsoft, New York, USA).

\section{Conclusions}

Tomato yield and the number of fruits were significantly influenced by cultivar but not by fertilization treatments. The treatment with a greater supply of water led to higher fruit yield. Indeed, the highest yield was achieved in the combination of the HTP $F_{1}$ cultivar under organic fertilization and $100 \%$ evapotranspiration replenishment.

The concentrations of phosphorus, calcium, nickel, and lead in the fruits of the Siriana $\mathrm{F}_{1}$ cultivar were higher under the $67 \%$ evapotranspiration replenishment and chemical fertilization, which suggest that these mineral elements are more easily absorbed by this cultivar as compared with HTP $F_{1}$ and Inima de Bou cultivars.

Macroelement concentrations of manganese and potassium in tomato fruits were affected by the fertilization type, phosphorus by cultivar and fertilization type, and calcium by all the factors examined. Microelement concentrations in tomato fruits were influenced by the treatments. Copper was affected by the fertilization type only, manganese and nickel by the cultivar and irrigation regime, and lead by all three factors. The positive effect of organic fertilization on the lycopene accumulation and antioxidant activity of tomato fruits showed that this fertilization type can be used as an alternative to chemical fertilization in sustainable agriculture, giving premium quality products. 
Author Contributions: V.S. and S.-C.I. conceived the research idea and protocol design; V.S. and A.C. coordinated the research and wrote the manuscript draft; G.C. and V.S. critically commented on and revised the manuscript draft, as well as finalized the final manuscript version; G.M. performed the statistical analysis and managed the phenol analyses; A.C. and G.-C.T. contributed to experiment management. All authors have read and agreed to the published version of the manuscript.

Funding: This research received no external funding.

Acknowledgments: The authors wish to thank the staff of the "Ion Ionescu de la Brad" University of Agricultural Sciences and Veterinary Medicine for economic support.

Conflicts of Interest: The authors declare no conflict of interest.

\section{References}

1. Faostat. 2018. Available online: http://faostat3.fao.org/browse/Q/QC/E (accessed on 13 May 2020).

2. INS. Vegetal Agriculture Production for Main Crops; INS, 2019; Volume 85, pp. 1-4.

3. Testa, R.; di Trapani, A.M.; Sgroi, F.; Tudisca, S. Economic sustainability of Italian greenhouse cherry tomato. Sustainability 2014, 6, 7967. [CrossRef]

4. Marti, R.; Rosello, S.; Cebolla-Cornejo, J. Tomato as a source of carotenoids and polyphenols targeted to cancer prevention. Cancers 2016, 8, 58. [CrossRef] [PubMed]

5. Dumas, Y.; Dadomo, M.; Di Lucca, G.; Grolier, P. Effects of environmental factors and agricultural techniques on antioxidant content of tomatoes. J. Sci. Food Agric. 2003, 83, 369-382. [CrossRef]

6. Guil-Guerrero, J.L.; Rebolloso-Fuentes, M.M. Nutrient composition and antioxidant activity of eight tomatoes (Lycopersicon esculentum) varieties. J. Food Compos. Anal. 2009, 22, 123-129. [CrossRef]

7. Ilahy, R.; Siddiqui, M.W.; Tlili, I.; Montefusco, A.; Piro, G.; Hdider, C.; Lenuci, M.S. When Color Really Matters: Horticultural Performance and Functional Quality of High-Lycopene Tomatoes. Crit. Rev. Plant Sci. 2018, 37, 15-53. [CrossRef]

8. Casals, J. Cherry and fresh market tomatoes: Differences in chemical, morphological, and sensory traits and their implications for consumer acceptance. Agronomy 2019, 9, 9. [CrossRef]

9. Caruso, G.; De Pascale, S.; Cozzolino, E.; Cuciniello, A.; Cenvinzo, V.; Bonini, P.; Colla, G.; Rouphael, Y. Yield and Nutritional Quality of Vesuvian Piennolo Tomato PDO as affected by Farming System and Biostimulant Application. Agronomy 2019, 9, 505. [CrossRef]

10. Caruso, G.; Villari, G.; Borrelli, C.; Russo, G. Effects of crop method and harvest seasons on yield and quality of green asparagus under tunnel in southern Italy. Adv. Hort. Sci. 2012, 26, 51-58.

11. Teliban, G.-C.; Stoleru, V.; Burducea, M.; Lobiuc, A.; Munteanu, N.; Popa, L.D.; Caruso, G. Biochemical, Physiological and Yield Characteristics of Red Basil as Affected by Cultivar and Fertilization. Agriculture 2020, 10, 48. [CrossRef]

12. Brunetti, G.; Traversa, A.; De Mastro, F.; Cocozza, C. Short term effects of synergistic inorganic and organic fertilization on soil properties and yield and quality of plum tomato. Sci. Hortic. 2019, 252, 342-347. [CrossRef]

13. Rouphael, Y.; Colla, G.; Giordano, M.; El-Nalchel, C.; Kyriacou, M.C.; De Pascale, S. Foliar applications of a legume-derived protein hydrolysate elicit dose-dependent increases of growth, leaf mineral composition, yield and fruit quality in two greenhouse tomato cultivars. Sci. Hortic. 2017, 226, 353-360. [CrossRef]

14. De Sio, F.; Rapacciuolo, M.; De Giorgi, A.; Sandei, L.; Giuliano, B.; Sekara, A.; Tallarita, A.; Morano, G.; Cuciniello, A.; Cozzolino, E.; et al. Yield and quality performances of organic tomato as affected by genotype and industrial processing in southern Italy. Italus Hortus 2020, 27, 85-99. [CrossRef]

15. Raigon, M.D.; Prohens, J.; Munoz-Falcon, J.E.; Nuez, F. Comparison of eggplant landraces and commercial varieties for fruit content of phenolics, minerals, dry matter and protein. J. Food Compos. Anal. 2008, 21, 370-376. [CrossRef]

16. Russo, V.M. Cultural methods and mineral content of eggplant (Solanum melongena) fruit. J. Sci. Food Agric. 1996, 71, 119-123. [CrossRef]

17. Arivalagan, M.; Gangopadhyay, K.K.; Kumar, G.; Bhardwaj, R.; Prasad, T.V.; Sarkar, S.K.; Roy, A. Variability in mineral composition of Indian eggplant (Solanum melongena L.) genotypes. J. Food Compos. Anal. 2012, 26, 173-176. [CrossRef]

18. Lombardo, S.; Pandino, G.; Mauromicale, G. The mineral profile in organically and conventionally grown "early" crop potato tubers. Sci. Hortic. 2014, 167, 169-173. [CrossRef] 
19. Sellitto, V.M.; Golubkina, N.A.; Pietrantonio, L.; Cozzolino, E.; Cuciniello, A.; Cenvinzo, V.; Florin, I.; Caruso, G. Tomato yield, quality, mineral composition and antioxidants as affected by beneficial microorganisms under soil salinity induced by balanced nutrient solutions. Agriculture 2019, 9, 110. [CrossRef]

20. Giuliani, M.M.; Gatta, G.; Cappelli, G.; Gagliardi, A.; Donatelli, M.; Fanchini, D.; DeNart, D.; Mongiano, G.; Bregaglio, $\mathrm{S}$. Identifying the most promising agronomic adaptation strategies for the tomato growing systems in Southern Italy via simulation modeling. Eur. J. Agron. 2019, 111, 125937. [CrossRef]

21. Herencia, J.F.; García-Galavís, P.A.; Maqueda, C. Long-term effect of organic and mineral fertilization on soil physical properties under greenhouse and outdoor management practices. Pedosphere 2011, 21, 443-453. [CrossRef]

22. Ronga, D.; Zaccardelli, M.; Lovelli, S.; Perrone, D.; Francia, E.; Milc, J.; Ulrici, A.; Pecchioni, N. Biomass production and dry matter partitioning of processing tomato under organic vs conventional cropping systems in a Mediterranean environment. Sci. Hortic. 2017, 224, 163-170. [CrossRef]

23. Gong, X.; Qiu, R.; Sun, J.; Ge, J.; Li, Y.; Wang, S. Evapotranspiration and crop coefficient of tomato grown in a solar greenhouse under full and deficit irrigation. Agric. Water Manag. 2020, 235, 106154. [CrossRef]

24. Coyago, E.; Corell, M.; Stinco, C.M.; Hernanz, D.; Moriana, A.; Meléndez-Martínez, A.J. Effect of regulated deficit irrigation on quality parameters, carotenoids and phenolics of diverse tomato varieties (Solanum lycopersicum L.). Food Res. Int. 2017, 96, 72-83. [CrossRef]

25. Wang, X.K.; Xing, Y.Y. Evaluation of the effects of irrigation and fertilization on tomato fruit yield and quality: A principal component analysis. Sci. Rep. 2017, 7, 1-13. [CrossRef] [PubMed]

26. Wang, J.; Niu, W.; Li, Y. Nitrogen and phosphorus absorption and yield of tomato increased by regulating the bacterial community under greenhouse conditions via the alternate drip irrigation method. Agronomy 2020, 10, 315. [CrossRef]

27. Adekiya, A.O. Green manures and poultry feather effects on soil characteristics, growth, yield, and mineral contents of tomato. Sci. Hort. 2019, 257, 1-7. [CrossRef]

28. Agarwal, S.; Rao, A.V. Tomato lycopene and its role in human health and chronic diseases. CMAJ 2000, 163, 739-744.

29. Inculet, C.S.; Mihalache, G.; Sellitto, V.M.; Hlihor, R.M.; Stoleru, V. The effects of a microorganisms-based commercial product on the morphological, biochemical and yield of tomato plants under two different water regimes. Microorganisms 2019, 7, 706. [CrossRef]

30. Jedrszczyk, E.; Ambroszczyk, A.M. The influence of NANO-GRO (R) organic stimulator on the yielding and fruit quality of field tomato (Lycopersicon esculentum Mill.). Folia Hortic. 2016, 28, 87-94. [CrossRef]

31. Burns, J.; Fraser, P.D.; Bramley, P.M. Identification and quantification of carotenoids, tocopherols and chlorophylls in commonly consumed fruits and vegetables. Phytochemistry 2003, 62, 939-947. [CrossRef]

32. Brandt, S.; Pék, Z.; Barna, É.; Lugasi, A.; Helyes, L. Lycopene content and colour of ripening tomatoes as affected by environmental conditions. J. Sci. Food Agric. 2006, 86, 568-572. [CrossRef]

33. Ordookhani, K.; Khavazi, K.; Moezzi, A.; Rejali, F. Influence of PGPR and AMF on the antioxidant activity, lycopene and potassium contents in tomato. Afr. J. Agric. Res. 2010, 5, 1108-1116.

34. Anton, D.; Matt, D.; Pedastsaar, P.; Bender, I.; Kazimierczak, R.; Roasto, M.; Kaart, T.; Luik, A.; Püssa, T. Three-Year Comparative Study of Polyphenol Contents and Antioxidant Capacities in Fruits of Tomato (Lycopersicon esculentum Mill.) Cultivars Grown under Organic and Conventional Conditions. J. Agric. Food Chem. 2014, 62, 5173-5180. [CrossRef] [PubMed]

35. Caruso, G.; Stoleru, V.; Munteanu, N.; Sellitto, V.M.; Teliban, G.C.; Burducea, M.; Tenu, I.; Morano, G.; Butnariu, M.V. Quality performances of sweet pepper under farming management. Not. Bot. Horti Agrobot. Cluj-Napoca 2018, 47, 458-464. [CrossRef]

36. Pinela, J.; Barros, L.; Carvalho, A.M.; Ferreira, I.C.F.R. Nutritional composition and antioxidant activity of four tomatoes (Lycopersicon esculentum L.) farmer' varieties in Northeastern Portugal homegardens. Food Chem. Toxicol. 2012, 50, 829-834. [CrossRef] [PubMed]

37. Hura, C.; Munteanu, N.; Stoleru, V. Heavy metals levels in soil and vegetables in different growing systems. In Proceedings of the E3S Web of Conferences, Rome, Italy, 23-27 September 2012; 2013. [CrossRef]

38. Munteanu, N.; Stoleru, V.; Hura, C. Assessment of heavy metals control from soil and vegetable plants in different growing systems. J. Agric. Sci. Technol. 2012, 2, 716-722.

39. Ordóñez-Santos, L.E.; Vázquez-Odériz, M.L.; Romero-Rodríguez, M.A. Micronutrient contents in organic and conventional tomatoes (Solanum lycopersicum L.). Int. J. Food Sci. Technol. 2011, 46, 1561-1568. [CrossRef] 
40. Suárez, M.H.; Rodríguez, E.R.; Romero, C.D. Mineral and trace element concentrations in cultivars of tomatoes. Food Chem. 2007, 104, 489-499. [CrossRef]

41. Allen, R.G.; Pereira, L.S.; Raes, D.; Smith, M. Crop Evapotranspiration: Guidelines for Computing Crop Requirements; FAO Irrigation and Drainage Paper No. 56; FAO: Rome, Italy, 1998.

42. Rippy, J.F.M.; Peet, M.M.; Louws, F.J.; Nelson, P.V.; Orr, D.B.; Sorensen, K.A. Plant development and harvest yields of greenhouse tomatoes in six organic growing systems. Hort. Sci. 2004, 39, 223-229. [CrossRef]

43. Butnariu, M.V.; Giuchici, C.V. The use of some nanoemulsions based on aqueous propolis and lycopene extract in the skin's protective mechanisms against UVA radiation. J. Nanobiotechnol. 2011, 9, 3. [CrossRef]

44. Mocan, A.; Vodnar, D.C.; Vlase, L.; Crisan, O.; Gheldiu, A.-M.; Cris an, G. Phytochemical characterization of Veronica officinalis L., V. teucrium L. and V. orchidea Crantz from Romania and their antioxidant and antimicrobial properties. Int. J. Mol. Sci. 2015, 16, 21109-21127. [CrossRef]

45. Vlase, L.; Benedec, D.; Hanganu, D.; Damian, G.; Csillag, I.; Sevastre, B.; Mot, A.C.; Silaghi-Dumitrescu, R.; Tilea, I. Evaluation of antioxidant and antimicrobial activities and phenolic profile for Hyssopus officinalis, Ocimum basilicum and Teucrium chamaedrys. Molecules 2014, 19, 5490-5507. [CrossRef] [PubMed]

46. Lotfi, S.; Kordsardouei, H.; Oloumi, H. Study of total phenolic content and antioxidant capacity of the ethanolic extracts of two medicinal plants, Hibiscus sabdariffa L. and Amaranthus caudatus L. Banat's J. Biotechnol. 2019, 10, 66-74. [CrossRef]

47. Butnariu, M.; Coradini, C.Z. Evaluation of biologically active compounds from Calendula officinalis flowers using spectrophotometry. Chem. Cent. J. 2012, 6, 1-7. [CrossRef] [PubMed]

(C) 2020 by the authors. Licensee MDPI, Basel, Switzerland. This article is an open access article distributed under the terms and conditions of the Creative Commons Attribution (CC BY) license (http://creativecommons.org/licenses/by/4.0/). 